\title{
DEVELOPMENT OF FIRE BRICKS FROM ORGANIC WASTE: AN ECO-FRIENDLY ENERGY SOLUTION
}

\author{
KHURSHID, I. ${ }^{1,2}-$ AHMAD, S. ${ }^{3 *}-$ NAWAZ, R. ${ }^{2}-$ ARSHAD, M. ${ }^{4}$ - DAR, M. E. U. I. ${ }^{5}$ - IMRAN, M. ${ }^{3}$ \\ - ASLAM, F. ${ }^{1}$ - NASIR, R. ${ }^{2}$ - SHAH, G. M. ${ }^{3}-$ AHMAD, N. ${ }^{3}$ - NAEEM, M. A. ${ }^{3}$ \\ ${ }^{I}$ Department of Environmental Sciences, Lahore College for Women University \\ Lahore, Pakistan \\ ${ }^{2}$ Department of Environmental Sciences, The University of Lahore, Lahore, Pakistan \\ ${ }^{3}$ Department of Environmental Sciences, COMSATS University Islamabad, Vehari Campus, \\ Pakistan \\ ${ }^{4}$ Department of Agriculture \& Food Technology, Karakoram International University \\ Gilgit, Pakistan \\ ${ }^{5}$ Department of Botany, University of Azad Jammu \& Kashmir, Muzaffarabad, Pakistan \\ *Corresponding author \\ sahmad.ait@gmail.com
}

(Received $16^{\text {th }}$ Mar 2018; accepted $24^{\text {th }}$ May 2018)

\begin{abstract}
The growing population poses serious threats not only to forests but also to the overall environment due to fuel and wood consumption used for various purposes. However, converting organic waste into fire bricks could be a useful step towards alternative energy sources. In the present study, fire bricks were prepared using organic waste i.e., cardboard, rice husk, saw dust, cow dung and newspapers. Firstly, the brick manufacturing materials were soaked in water in various ratios and converted into paste with mortar and pestle to make bricks. Secondly, the fire bricks were analyzed for gas emissions, burning time period, flue gas temperature and net efficiency. The results reveal that gas emissions were below the National Environmental Quality Standards (NEQS). Moreover, the results were also compared with a commonly used fuel wood (Vachellia karroo) to calculate the statistical variations for various parameters. Thus, the net efficiency range of fire bricks was from 39.7 to $58.9 \%$, significantly higher than that of the fuel wood. The flue gas temperature varied from 230 to $430{ }^{\circ} \mathrm{C}$. Therefore, the bricks were found to have high heat intensity, to be easy to use, and to have needed small space for their storage. Additionally, fire bricks are cost-effective compared to fuel wood. It is concluded that high quality and durable fire bricks can be made while using a combination of rice husk and newspapers (RHNP), rice husk and cardboard (RHCB), sawdust and cardboard (SDCB), cow dung and cardboard (CDCB), cow dung and newspapers (CDNP), sawdust and cow dung (SDCD) in a ratio of 2:3. It is due to all these benefits, that fire bricks were considered eco-friendlier in efficiency than fuel wood.
\end{abstract}

Keywords: fire bricks, alternative energy, fuel wood, biomass recycling, waste management

\section{Introduction}

Energy is a crucial and significant factor for socioeconomic development in any country. However, the ever-growing population is putting more pressure on energy sources. It is said that both sufficient and cost effective energy resources are essential for the steady development around the globe. The energy demand is raised with urbanization and industrialization. Thus, fossil fuel is excessively used around the world for urbanization and modernization. Coal, oil and gas meet $80 \%$ of the energy requirements of the world, however; contribution of renewable energy resources and 
nuclear power in energy sector is $13.1 \%$ and $6.5 \%$, respectively in the total energy demands (IEA, 2007).

Municipal solid waste is being generated in large amounts with low gas emissions threatening the environmental health. In order to collect, store, process, and dispose the municipal solid waste, usually unsuitable practices are being employed. These unfit techniques in turn harm the health of humans, plants and animals. Suitable and secure management of solid waste is deemed necessary, especially in an area which is denser for better environmental health. In developing countries, waste after its collection is generally discarded on land surface without any protection that causes water and air pollution (Dong et al., 2003; Mosler et al., 2006).

Recently, it has been witnessed that the fossil fuel scarcity is increasing with high energy requirements around the world. It is need of the hour to go for environmentfriendly and sustainable alternate energy resources. The interest of switching towards alternate energy sources will not only substitute fossil fuels but it is also good for environmental health. Conventional fuel like firewood is rapidly declining which increases dependency on innovative sources of energy for household usage (Kavitha and Joseph, 2007).

Wood and charcoal had been considered as renewable energy sources and agricultural waste is available in sufficient amounts in rural areas. The residues like rice husk, sawdust, corn stover and cotton stalk are best options to be used for cooking purposes at household level. However, the use of these residues without processing is problematic due to their raw form which produces large amounts of smoke, leading to air pollution. Biomass resources when burned in their raw form generate less heat and have low mass to volume ratio. All these factors lead to poor efficiency to use them as fuel (Emerhi, 2011). Moreover, it is not convenient to use, transport and store these agricultural residues in their pure form.

Massive flammable materials are compacted to make them feasible for using as fuel. Thus, this technique is becoming popular around the globe. Fuel bricks have been produced to use not only for household purposes but also for industries. The reason behind the production of fire bricks is to meet the growing energy requirements and to protect the environment from the harms of traditional fuels. At the same time, this technique also manages crop remains in a very efficient way (Vongsaysana, 2009). Moreover, heat efficiency of these crop residues can also be intensified by converting them into fuel bricks (Wilaipon, 2007).

Calorific values of the agricultural and organic residues would increase in brick form due to compaction. The loose agricultural wastes have lower calorific value which is difficult to handle (Oladeji, 2010). For electricity production, industrial use and for cooking food, the use of fire bricks can be a good option (Styles et al., 2008). Therefore, the present study aims to switch traditional use of fuel wood to the high energy efficient and environment-friendly alternative energy sources through agricultural and other organic residue-based fire bricks.

\section{Materials and methods}

\section{Study area description}

The current study was carried out in the Punjab Province of Pakistan which is renowned for its agricultural based economy. Geographic location of the study area is 
$30.183^{\circ}$ latitude and $73.06^{\circ}$ longitude. All the waste material used in this study was collected and processed for brick development in the district Pakpattan of the province.

\section{Collection and preparation of samples}

Cardboard and newspapers were collected from shops. Likewise, rice husk was collected from rice grinding mills and sawdust from carpenter shop. Fresh cow dung was collected from cow farm house. Similarly, rice husk and sawdust were cleaned to remove dirt and undesirable particles. Newspapers were torn into the smallest possible pieces. These pieces were placed in the bucket and soaked in water for 24,48 and $72 \mathrm{~h}$. Table 2 shows the effects of soaking time on quality of fire bricks.

These samples were converted into paste while using grinder. The same procedure was repeated for cardboard sample preparation, and cardboard sample was also converted into paste while using crusher. This practice was adopted to check the most suitable combination and quality of sample materials to convert them into smooth bricks. The quality of sampling combinations in different ratios was ranked in three different categories such as good, average and best. Only the best quality rank was proceeded further for analysis. The quality (average, good and best) of the fire bricks was based on the measurement of porosity and dry bulk density of the bricks (Table 1). The porosity $(n)$ of a material indicates the storage capacity of a porous medium. It is a fraction of the voids in total volume of the porous medium ( $E q .1)$. The dry bulk density $\left(\rho_{b}\right)$ is calculated from the dry mass of the material and its total volume (Eq. 2) (Fetter, 2001).

$$
\begin{gathered}
n(\%)=\frac{V_{v}}{V_{t}} \times 100=\frac{V_{w}}{V_{t}} \times 100 \\
\rho_{b}\left(g / \mathrm{cm}^{3}\right)=\frac{m_{s}}{V_{t}}
\end{gathered}
$$

where $V_{v}$ is the volume of voids which is equal to volume of water $V_{w}$ in saturated medium, $V_{t}$ is total volume and $m_{s}$ is dry mass of the material.

Table 1. Criteria used for the quality of fire bricks

\begin{tabular}{c|c|c|c|c|c}
\hline \multicolumn{3}{c|}{ Porosity (\%) } & \multicolumn{3}{c}{ Dry bulk density (g/cm $\left.{ }^{3}\right)$} \\
\hline Average & Good & Best & Average & Good & Best \\
\hline $35-60$ & $73-90$ & $60-72$ & $0.31-0.5$ & $0.15-0.3$ & $0.1-0.15$ \\
\hline
\end{tabular}

Vachellia karroo (formerly known as Acacia karroo) is a fast growing tree and is abundantly found in Pakistan, India, Nepal and Africa. It is commonly found along highways, canals, river sides, rangelands and among the major trees considered for agro-forestry in Pakistan. It produces high-density wood $\left(800-890 \mathrm{~kg} / \mathrm{m}^{3}\right)$ which is commonly used for fuel wood besides other beneficial uses. Fuel wood of Vachelli karroo was used as control in this study (Fig. la). 


\section{Binder preparation and formation of bricks}

Wheat flour was used to prepare binder. Hot water was added into it to prepare its paste. It was assured that no lumps were produced. Binder was muggy, it did strengthen the samples. The volume of binder varies in different types of combinations depending that a homogeneous mixture is formed. Newspaper (NP) paste was taken and placed into brick mould box, levelled and pressed to make it compact. Afterwards, the mould box was emptied in an outdoor dry place under natural conditions. Three NP bricks were made in this way while three cardboard (CB) bricks were also prepared with the same procedure. The rice husk (RH) sample was taken and thoroughly mixed with binder until the paste was obtained. This paste was placed in brick mould box and was levelled. The same procedure was adopted and repeated for the combination of SDNP, SDCB, RHCD, RHNP, RHCB, CDNP, CDCB, and NPCB. Table 2 shows the sample combinations in different treatments. The ratios of wastes were based on the volume. The same procedure was repeated for various ratios like 1:9, 7:3, 3:2, and 1:4 respectively. Three bricks of each combination were made. A metallic template was used for the formation of bricks. The volume of each prepared brick was $1823 \mathrm{~cm}^{3}$ with dimensions of $22.86 \mathrm{~cm}$ length, $11.43 \mathrm{~cm}$ width and $6.98 \mathrm{~cm}$ height. The shape of prepared bricks is shown in Figure $1 b, c$ and $d$.

\section{Cost-effectiveness measurements of fire bricks}

Market prices of the organic wastes (newspaper, sawdust, rice husk, cardboard and cow dung) were collected and then were compared with the market price of hard wood as control. Cost-effectiveness of fire bricks made of organic waste was calculated. Prices were calculated in US dollars. The price for waste material includes labor charges to prepare fuel bricks (2 persons/day and charges are $3.48 \mathrm{USD} /$ day/person). The prices for dry waste are as newspaper $2.61 \mathrm{USD} / 40 \mathrm{~kg}$, cow dung $0.35 \mathrm{USD} / 40 \mathrm{~kg}$, cardboard $3.10 \mathrm{USD} / 40 \mathrm{~kg}$, sawdust $1.66 \mathrm{USD} / 40 \mathrm{~kg}$, rice husk $2.78 \mathrm{USD} / 40 \mathrm{~kg}$.

\section{Analysis of fire bricks for gaseous emissions}

Combustion analysis was carried out to measure gas emissions from fire bricks. The system contained weight meter, a stove with ceramic lining and chimney. The Testo 350 flue gas analyzer connected to the chimney was used to measure the emissions, flue gas temperature, net efficiency, gross efficiency, and burning period. In present research, the fuel bricks were burned in the stove of ceramic lining. The emissions of burning of fuel bricks were observed in $\mathrm{mg} / \mathrm{Nm}^{3}$ and then compared with National Environmental Quality Standards (NEQS) for stack emissions. NEQS values for CO, Oxides of Nitrogen and Oxides of Sulphure are $800 \mathrm{mg} / \mathrm{Nm}^{3}, 600 \mathrm{mg} / \mathrm{Nm}^{3}$ and $1700 \mathrm{mg} / \mathrm{Nm}^{3}$, respectively. However, NEQS for smoke number is 2 on Ringleman Scale (GOP, 2016).

\section{Statistical analysis}

MS-Excel (2010) was used for statistical analysis. Descriptive statistics such as percentage, average, were applied to process results of density, porosity, gas emissions and cost-effectiveness of fire bricks. ANOVA was performed for different parameters at significance level of 1\%. Degree of freedom (df), sum of squares (SS) and mean sum of squares (MSS) were calculated for different source of variation (SoV). 
Table 2. Effect of organic waste types, their combinations and soaking time on the quality of fire bricks

\begin{tabular}{|c|c|c|c|c|c|}
\hline Combinations & & Treatments & Abbreviations & $\begin{array}{l}\text { Soaking time } \\
\text { (hours) }\end{array}$ & Quality \\
\hline \multirow{5}{*}{ Individual Material } & T1 & Newspaper & $\mathrm{NP}$ & 48 & Good \\
\hline & $\mathrm{T} 2$ & Cardboard & $\mathrm{CB}$ & 48 & Good \\
\hline & $\mathrm{T} 3$ & Sawdust & SD & 00 & Average \\
\hline & $\mathrm{T} 4$ & Rice husk & $\mathrm{RH}$ & 00 & Average \\
\hline & $\mathrm{T} 5$ & Cow dung & $\mathrm{CD}$ & 00 & Good \\
\hline \multirow{10}{*}{ Combinations $(1: 1)$} & T6 & Sawdust and rice husk & SDRH & 00 & Average \\
\hline & $\mathrm{T} 7$ & Sawdust and cow dung & SDCD & 00 & Good \\
\hline & $\mathrm{T} 8$ & Sawdust and newspaper & SDNP & 24 & Good \\
\hline & $\mathrm{T} 9$ & Sawdust and cardboard & SDCB & 24 & Good \\
\hline & $\mathrm{T} 10$ & Rice husk and cow dung & RHCD & 00 & Good \\
\hline & $\mathrm{T} 11$ & Rice husk and newspaper & RHNP & 24 & Good \\
\hline & $\mathrm{T} 12$ & Rice husk and cardboard & RHCB & 24 & Good \\
\hline & $\mathrm{T} 13$ & Cow dung and newspaper & CDNP & 24 & Good \\
\hline & $\mathrm{T} 14$ & Cow dung and cardboard & $\mathrm{CDCB}$ & 24 & Good \\
\hline & $\mathrm{T} 15$ & Newspaper and cardboard & NPCB & 24 & Good \\
\hline \multirow{8}{*}{ Combinations (1:9) } & T16 & Sawdust and cow dung & SDCD & 00 & Good \\
\hline & $\mathrm{T} 17$ & Sawdust and newspaper & SDNP & 48 & Good \\
\hline & $\mathrm{T} 18$ & Sawdust and cardboard & SDCB & 48 & Good \\
\hline & T19 & Rice husk and cow dung & RHCD & 00 & Good \\
\hline & $\mathrm{T} 20$ & Rice husk and newspaper & RHNP & 48 & Good \\
\hline & $\mathrm{T} 21$ & Rice husk and cardboard & RHCB & 48 & Good \\
\hline & $\mathrm{T} 22$ & Cow dung and newspaper & CDNP & 48 & Good \\
\hline & $\mathrm{T} 23$ & Cow dung and cardboard & $\mathrm{CDCB}$ & 48 & Good \\
\hline \multirow{8}{*}{ Combinations (1:4) } & $\mathrm{T} 24$ & Sawdust and cow dung & SDCD & 00 & Good \\
\hline & $\mathrm{T} 25$ & Sawdust and newspaper & SDNP & 48 & Good \\
\hline & $\mathrm{T} 26$ & Sawdust and cardboard & SDCB & 48 & Good \\
\hline & $\mathrm{T} 27$ & Rice husk and cow dung & RHCD & 00 & Good \\
\hline & $\mathrm{T} 28$ & Rice husk and newspaper & RHNP & 48 & Good \\
\hline & $\mathrm{T} 29$ & Rice husk and cardboard & RHCD & 48 & Good \\
\hline & $\mathrm{T} 30$ & Cow dung and newspaper & CDNP & 48 & Good \\
\hline & $\mathrm{T} 31$ & Cow dung and cardboard & $\mathrm{CDCB}$ & 48 & Good \\
\hline \multirow{8}{*}{ Combinations (2:3) } & T32 & Rice husk and newspaper & RHNP & 72 & Best \\
\hline & $\mathrm{T} 33$ & Rice husk and cardboard & RHCB & 72 & Best \\
\hline & $\mathrm{T} 34$ & Sawdust and cardboard & SDCB & 72 & Best \\
\hline & T35 & Cow dung and cardboard & $\mathrm{CDCB}$ & 72 & Best \\
\hline & T36 & Cow dung and newspaper & CDNP & 72 & Best \\
\hline & $\mathrm{T} 37$ & Sawdust and cow dung & SDCD & 72 & Best \\
\hline & $\mathrm{T} 38$ & Sawdust and newspaper & SDNP & 72 & Good \\
\hline & T39 & Rice husk and cow dung & RHCD & 72 & Good \\
\hline \multirow{8}{*}{ Combinations (3:7) } & $\mathrm{T} 40$ & Sawdust and cow dung & SDCD & 00 & Good \\
\hline & $\mathrm{T} 41$ & Sawdust and newspaper & SDNP & 48 & Good \\
\hline & $\mathrm{T} 42$ & Sawdust and cardboard & SDCB & 48 & Good \\
\hline & $\mathrm{T} 43$ & Rice husk and cow dung & RHCD & 00 & Good \\
\hline & $\mathrm{T} 44$ & Rice husk and cardboard & RHCB & 48 & Good \\
\hline & $\mathrm{T} 45$ & Cow dung and newspaper & CDNP & 48 & Good \\
\hline & $\mathrm{T} 46$ & Cow dung and cardboard & $\mathrm{CDCB}$ & 48 & Good \\
\hline & $\mathrm{T} 47$ & Rice husk and newspaper & RHNP & 48 & Good \\
\hline
\end{tabular}




\section{Results and discussion}

Fire bricks of individual materials were found to be difficult to form besides their quality remained average. However, when all treatments were used in combinations, it not only improved their quality but also made their formation easy. Bricks of individual materials: newspaper (T1), cardboard (T2) and cow dung (T5) were made. Out of these treatments, bricks with T1 and T2 were of good quality, while T5 fire bricks were of best quality. It was difficult to make fire bricks from treatments T3 (sawdust) and T4 (rice husk) as individual materials due to their physical properties as both were in powder form. Even the quality of fire bricks prepared from sawdust and rice husk in the presence of binder was also very poor. Sawdust and rice husk can be used along with other waste materials in order to make fire bricks. Apparently, the surface of fire bricks was smooth and homogeneous (Fig. 1).

(a) Fuel wood of Vachellia Karroo (as control)

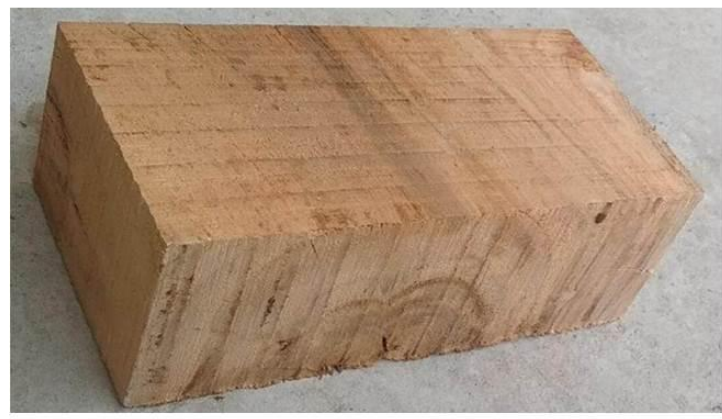

(c) Rice husk and Newspaper

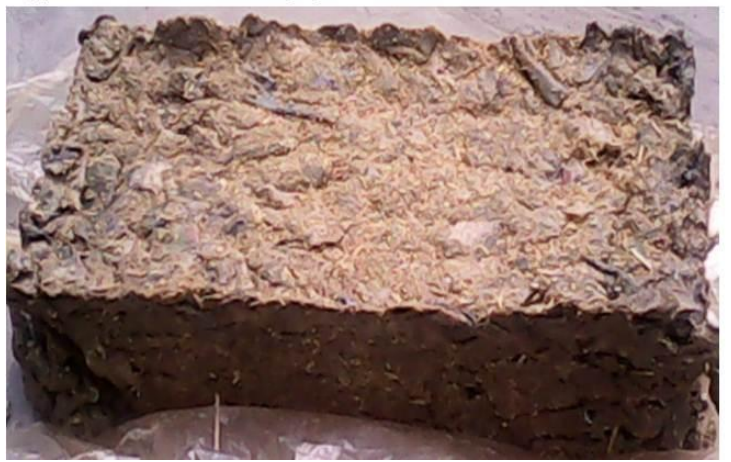

(b) Rice husk and Cow dung

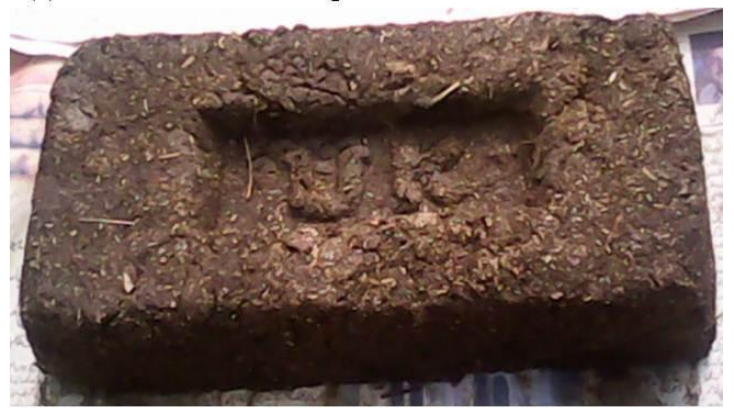

(d) Cardboard and Cow dung

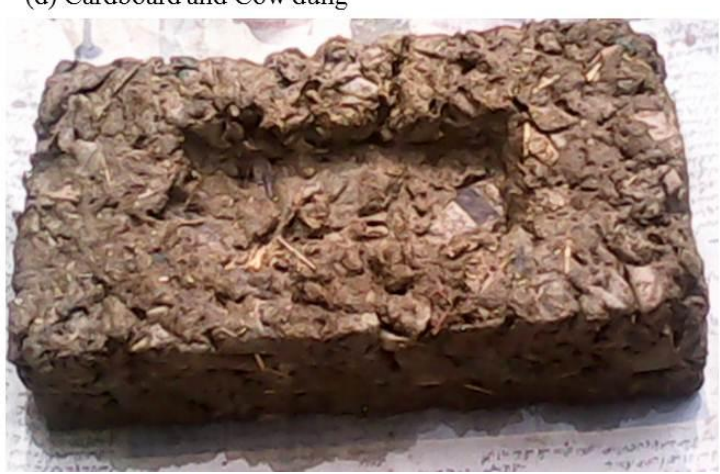

Figure 1. Fuel wood (as control) and samples of prepared bricks from organic wastes

It was found that fresh cow dung did not require soaking. Sawdust and rice husk were not soaked because they were used with paste of others. Only newspapers and cardboard were soaked. Various soaking periods were used to create homogeneous moisture in the mixture of materials for formation of bricks. Quality of six combinations (T32-T37) with a soaking period of $72 \mathrm{~h}$ was found to be the best, which was further studied (details in Table 2).

\section{Amount of carbon monoxide and carbon dioxide in fire brick exhaust}

Figure 2 shows the amount of oxygen, $\mathrm{CO}$ and $\mathrm{CO}_{2}$ in the exhaust of fire bricks. Amount of $\mathrm{CO}$ varied significantly with treatments from T32 to T37. The lowest CO was observed in T32 (RHNP) and the highest CO emissions were found in T35 
(CDCB). Emission of CO was within NEQS in case of T32 (RHNP), T33 (RHCB) and $\mathrm{T} 37$ (SDCB). Carbon monoxide (CO) emissions were the lowest as $265 \mathrm{mg} / \mathrm{Nm}^{3}$ in $\mathrm{T} 32$ and the highest as $3002 \mathrm{mg} / \mathrm{Nm}^{3}$ in T35 (Fig. 2a) however, NEQS for CO is 800 $\mathrm{mg} / \mathrm{Nm}^{3}$. All values were lower than the ones of NEQS (GOP, 2016) while only T37 (SDCD) emission value meets the ones of NEQS because of their composition. Ishrat and Lakshami (2014) conducted a study at Hyderabad, India to make fuel briquettes from mixture of paper, rice husk and sawdust and emission analysis of combustion of these briquettes was $84.77 \mathrm{mg} / \mathrm{Nm}^{3} \mathrm{CO}$ that is much lower than that of this study.

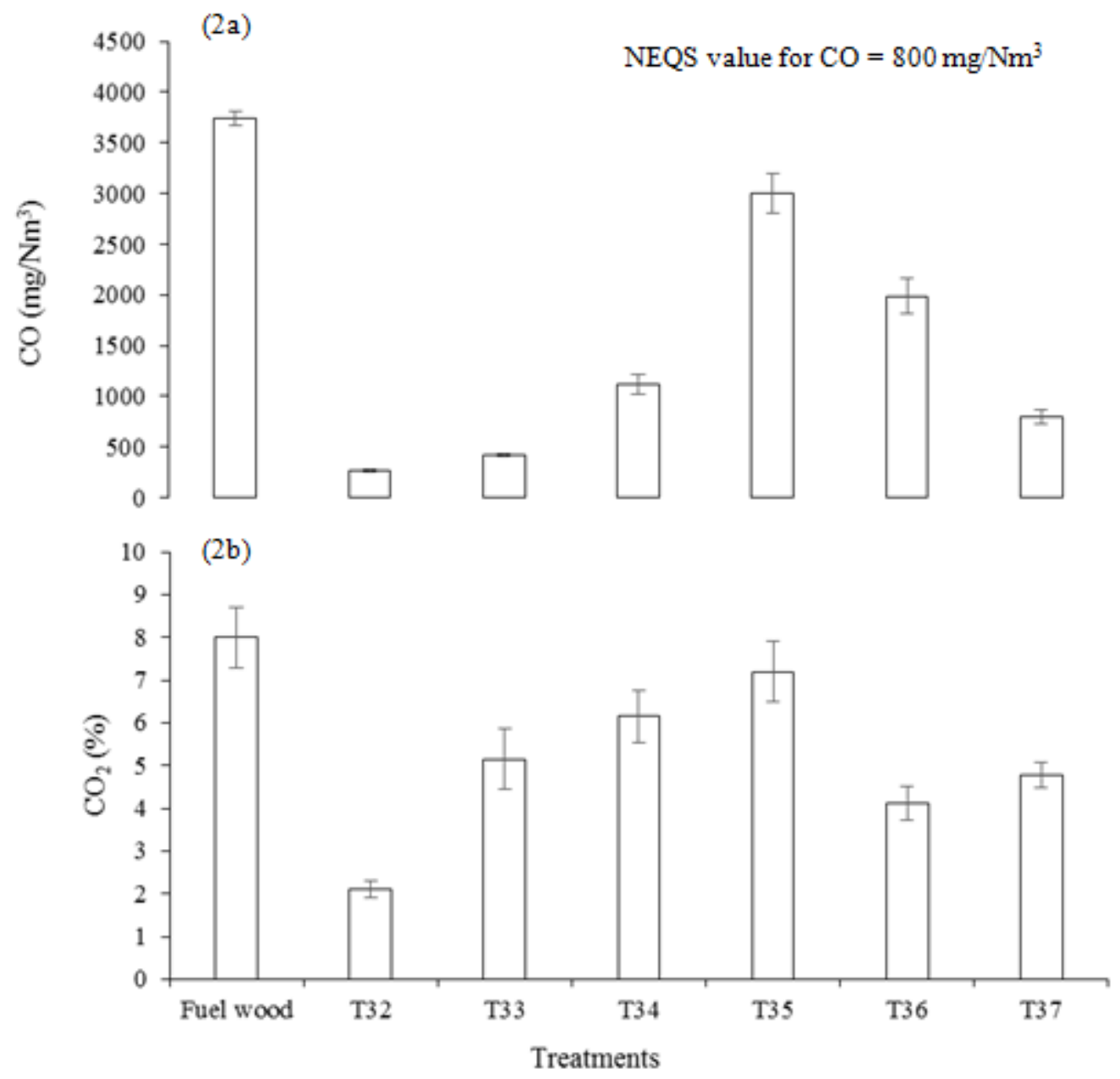

Figure 2. Amount of $\mathrm{CO}$ and $\mathrm{CO}_{2}$ in the fire brick exhaust

Figure $2 b$ indicates the results of $\mathrm{CO}_{2}$ emission from fire bricks. It was observed that the highest carbon dioxide emission was seen in T35 (CDCB) and the lowest in T32 (RHNP). Carbon dioxide $\left(\mathrm{CO}_{2}\right)$ emission was the lowest $2.1 \%$ in $\mathrm{T} 32$ and the highest $7.2 \%$ in T35. The lower $\mathrm{CO}_{2}$ emission was due to the combination of biomass NPRH in T32. According to Maia et al. (2014), when biomass fuel bricks were analyzed for emissions of $\mathrm{CO}_{2}$ the resultant value was $18.56 \%$, which is much higher than that of the present study. In another study, carbon dioxide values were found as $50 \%$ for wood chips and paper, and sawdust and paper, and $30 \%$ for sugarcane and paper. Evans, S (2014) reported 10 times lower carbon emissions from burning organic residues like 
branches, twigs and sawdust than in case of fuel wood coals. However, Fernandes et al. (2013) revealed that the biomass briquettes showed a greater release of $\mathrm{CO}_{2}$ with a peak of $0.48 \%$. Lower oxygen concentration caused higher $\mathrm{CO}$ concentration during combustion.

\section{Amount of $\mathrm{NO}$ and $\mathrm{NO}_{x}$ in fire brick exhaust}

It was observed that $\mathrm{NO}$ emission from fire bricks slightly varied from one another. T32 (RHNP) and T35 (CBCD) showed almost similar and the highest emission of NO than others, while T33 (RHCB) showed the lowest emission of NO (Fig. 3a). The minimum observed nitric oxide (NO) emission value was $106.7 \mathrm{mg} / \mathrm{Nm}^{3}$ in T33 and the maximum was $324 \mathrm{mg} / \mathrm{Nm}^{3}$ in T35. The relevant literature shows $2.45 \mathrm{mg} / \mathrm{Nm}^{3}$ when biomass fuel bricks were analyzed for NO that is much lower than that of the present study. High nitrogen contents, resulting in an elevated emission of dust and NOx, are still a matter of investigation on the use of herbaceous biomass at small-scale household appliances (Energy Commission of Ghana, 2008).
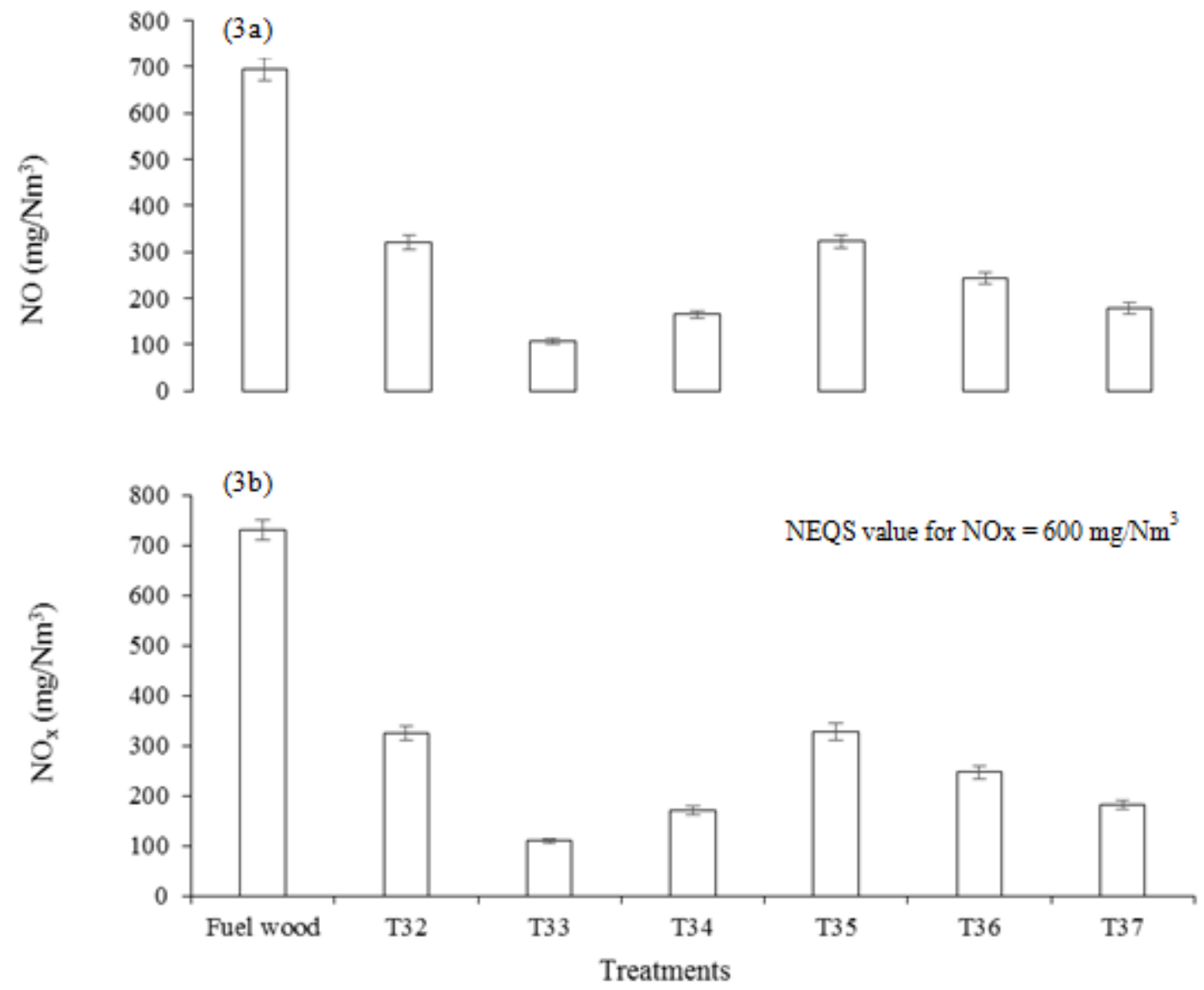

Figure 3. Amount of $N O$ and $N O_{x}$ in fire brick exhaust

Figure $3 b$ shows NOx emissions from fire bricks. It was observed that NOx emissions varied significantly from $\mathrm{T} 32$ to $\mathrm{T} 37$. The highest NOx emissions $\left(327 \mathrm{mg} / \mathrm{Nm}^{3}\right)$ were observed in T32 (RHNP) and T35 (CDCB), while T33 (RHCB) 
showed the lowest $\left(109.3 \mathrm{mg} / \mathrm{Nm}^{3}\right)$ NOx emissions. It is stated that all of the NOx emissions during burning the bricks were below those of the NEQS.

\section{Amount of $\mathrm{SO}_{2}$ in fire brick exhaust}

Figure 4 indicates the $\mathrm{SO}_{2}$ released from burning the fire bricks. It was observed that $\mathrm{T} 35$ (CDCB) liberated the highest emissions of $\mathrm{SO}_{2}$. The lowest emission was observed in T32 (RHNP).

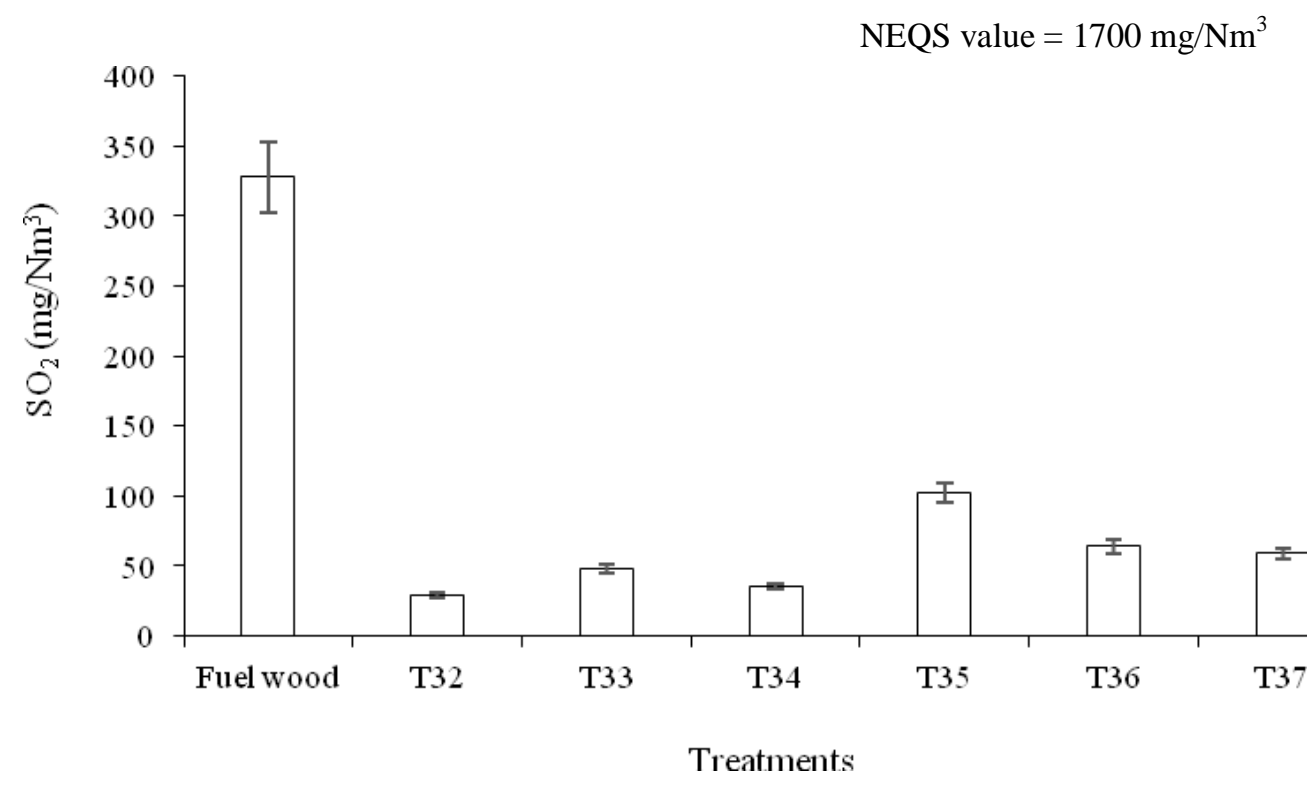

Figure 4. Amount of $\mathrm{SO}_{2}$ in fire brick exhaust

The minimum sulphur dioxide $\left(\mathrm{SO}_{2}\right)$ emissions - $29 \mathrm{mg} / \mathrm{Nm}^{3}$ - were also observed in $\mathrm{T} 32$ and the maximum $-102.6 \mathrm{mg} / \mathrm{Nm}^{3}$ - in $\mathrm{T} 35$ (Fig. 4). Even the maximum observed value was lower than that of the NEQS which is $1700 \mathrm{mg} / \mathrm{Nm}^{3}$. The reason behind this is the composition of fire bricks. When biomass of fire bricks was analyzed to determine their $\mathrm{SO}_{2}$ emissions, they were $167.7 \mathrm{mg} / \mathrm{Nm}^{3}$ (Enweremadu, et al., 2004) which were greater than those of the present study. Less concentration of nitrogen and sulphur was found in fire bricks smoke, which means less polluted atmosphere. This shows that if fire bricks will be used for heat, they will not harm the environment (Enweremadu, et al., 2004). The oxides of nitrogen and sulphur produce nitric and sulphuric acid which cause acid rain (Chaney, 2010).

Combustion of wood and coal as fuel causes air pollution, which in turn damages the health of human beings. One cubic meter of fuel wood release $61-73 \mathrm{~kg}$ of $\mathrm{CO}_{2}$. Longer exposures to the gases such as carbon monoxide (CO), sulphur oxides ( $\mathrm{SOx}$ ) and nitrogen oxide (NOx) cause harm to human health (Raymer, 2006).

Table 3 shows results of the statistical analysis (ANOVA) for different gases in exhaust from burning of different types of fuel bricks. It is clear that there is significant difference between gaseous emissions from burning of fuel bricks. Emission of gases $\left(\mathrm{CO}, \mathrm{CO}_{2}, \mathrm{NO}, \mathrm{NOx}\right.$ and $\mathrm{SO}_{2}$ ) has been significantly reduced for fuel bricks as compared to that of commonly used fuel wood. 
Table 3. Statistical analysis (ANOVA) for different gases in exhaust

\begin{tabular}{c|c|c|c|c|c|c}
\hline Parameter & SOV & df & SS & MSS & $\mathbf{F}_{\text {Cal. }}$ & $\mathbf{F}_{\text {Tab. }}$ \\
\hline \multirow{3}{*}{$\mathrm{CO}$} & Treatments & 6 & 30272032.34 & 5045338.72 & $101.83^{*}$ & 4.46 \\
& Error & 14 & 693667.79 & 49547.70 & -- & -- \\
& Total & 20 & 30965700.13 & -- & -- & -- \\
\hline \multirow{3}{*}{$\mathrm{CO}_{2}$} & Treatments & 6 & 78.29 & 13.05 & $12.27^{*}$ & 4.46 \\
& Error & 14 & 14.89 & 1.06 & -- & -- \\
& Total & 20 & 93.19 & -- & -- & -- \\
\hline \multirow{3}{*}{$\mathrm{NO}$} & Treatments & 6 & 692193.87 & 115365.64 & $319.35^{*}$ & 4.46 \\
& Error & 14 & 5057.53 & 361.25 & -- & -- \\
& Total & 20 & 697251.40 & -- & -- & -- \\
\hline \multirow{3}{*}{$\mathrm{NOx}$} & Treatments & 6 & 782367.46 & 130394.58 & $988.39^{*}$ & 4.46 \\
& Error & 14 & 1846.97 & 131.93 & -- & -- \\
& Total & 20 & 784214.43 & -- & -- & -- \\
\hline \multirow{3}{*}{$\mathrm{SO}_{2}$} & Treatments & 6 & 203766.11 & 33961.02 & $592.95^{*}$ & 4.46 \\
& Error & 14 & 801.85 & 57.27 & -- & -- \\
& Total & 20 & 204567.96 & -- & -- & -- \\
\hline
\end{tabular}

* indicates significant difference between treatment

\section{Net efficiency, flue gas temperature and burning time for fire bricks}

Figure $5 a$ indicates that the net efficiency of fire bricks slightly varied from T32 to T37. It was observed that the highest net efficiency was found in T37 (SDCD), and the lowest net efficiency was observed with treatment T36 (CDNP). The net efficiency which is the efficiency of solid burned particles of fire bricks was minimum $(39.7 \%)$ with treatment T36 and maximum 58.9\% with T37. In Latvia, a study was conducted to make fire briquettes from woody and non-woody herbaceous resources like grain husk. According to combustion analysis of those fire briquettes, the net energy production was 15.6 to $17.7 \mathrm{MJ} / \mathrm{Kg}$.

Flue gas temperature was measured to determine the efficiency of fire bricks. Figure $5 b$ shows flue gas temperature while burning the fire bricks. It was observed that flue gas temperature was the highest in case of T35 (CDCB). In case of T36 (CDNP) and T37 (SDCD) same flue gas temperature was found, and it was the lowest for T32 (RHNP). Minimum temperature was $230{ }^{\circ} \mathrm{C}$ in $\mathrm{T} 32$ and maximum was $450.2^{\circ} \mathrm{C}$. The combustion analysis of flue bricks gave flue gas temperature variation from 331 to $474^{\circ} \mathrm{C}$.

Fernandes et al. (2013) found that carbon, hydrogen and oxygen are the major constituents of biomass fuels. Carbon and hydrogen are oxidized to make $\mathrm{CO}_{2}$ and $\mathrm{H}_{2} \mathrm{O}$ which are responsible for high calorific value of the bricks. According to Ringleman scale, the smoke number indicates the apparent density of smoke, the greater the smoke number the greater the amount of particulate matter in the bricks. Minimum smoke number was 1.4 with treatment T33 (RHCB) and maximum 5.3 with T35 (CDCB) as shown in Figure $5 b$. While the NEQS for smoke number is 2 on the Ringleman scale. Maia et al. (2014) produced banana leaves fuel briquettes and found that in combustion tests, heavy smoke production was attributed to the fact that oxygen was supplied in 
uncontrolled way. Therefore, it is important to provide sufficient oxygen to convert $\mathrm{CO}$ to $\mathrm{CO}_{2}$ and minimize the smoke.
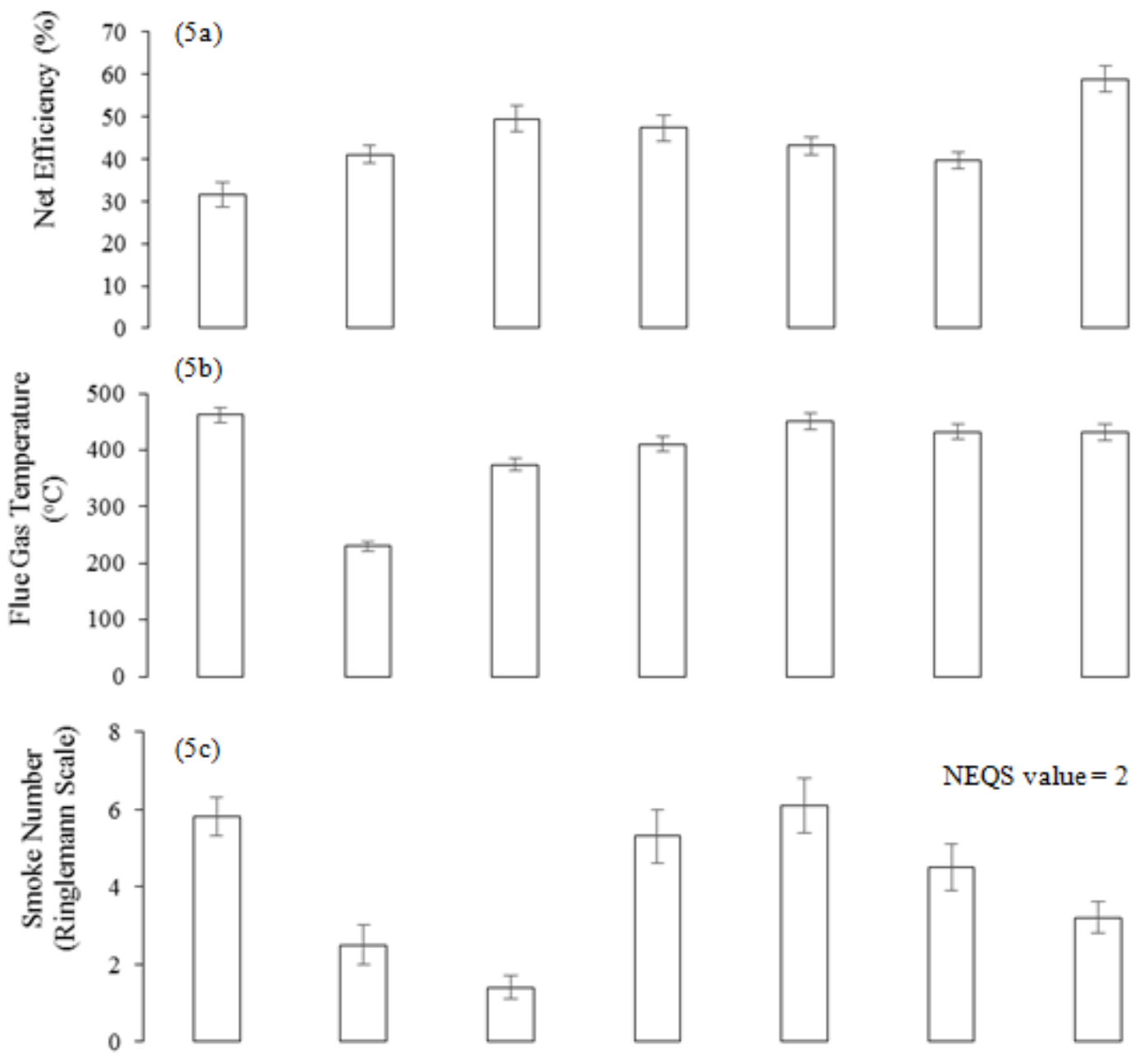

$\mathrm{NEQS}$ value $=2$
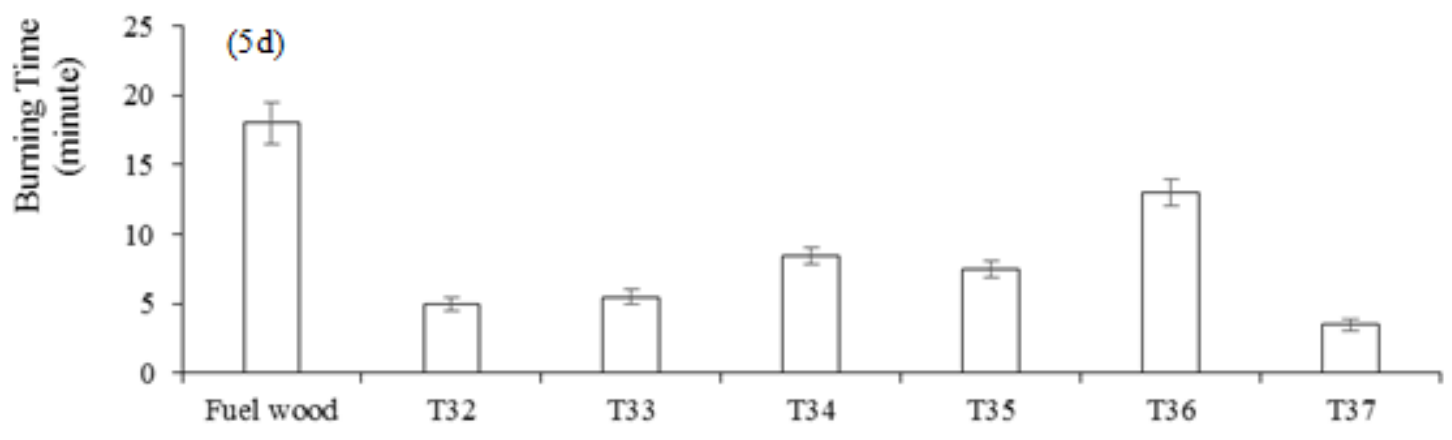

Treatments

Figure 5. Net efficiency, flue gas temperature and burning time for fire bricks

Figure $5 d$ shows burning time or duration of burning of fire bricks. It was observed that burning period was the highest for T36 (CDNP) and the lowest in case of T37 (SDCD). Burning period was observed as the lowest in T37 (4 min) and the highest was 13 min with treatment T36. 
Table 4 shows results of statistical analysis of variance (ANOVA) for net efficiency, flue gas temperature and burning time of bricks. It is clear that there is significant difference between treatments for net efficiency, smoke number and burning time. However, there is non-significant difference between treatments in case of flue gas temperature. It shows that there is no effect on flue gas temperature for different types of fuel bricks.

Table 4. Statistical analysis (ANOVA) for net efficiency, flue gas temperature and burning period of bricks

\begin{tabular}{c|c|c|c|c|c|c}
\hline Parameter & SOV & df & SS & MSS & F $_{\text {Cal. }}$ & F $_{\text {Tab. }}$ \\
\hline \multirow{4}{*}{ Net efficiency } & Treatments & 6 & 1325.53 & 220.92 & $19.53^{*}$ & 4.46 \\
& Error & 14 & 158.34 & 11.31 & -- & -- \\
& Total & 20 & 1483.87 & -- & -- & -- \\
\hline \multirow{2}{*}{ Flue gas } & Treatments & 6 & 133200.59 & 22200.10 & $3.05^{\text {ns }}$ & 4.46 \\
temperature & Error & 14 & 102041.30 & 7288.66 & -- & -- \\
& Total & 20 & 235241.89 & -- & -- & -- \\
\hline \multirow{3}{*}{ Smoke number } & Treatments & 6 & 57.40 & 9.57 & $58.40^{*}$ & 4.46 \\
& Error & 14 & 2.29 & 0.16 & -- & -- \\
\hline \multirow{2}{*}{ Burning time } & Total & 20 & 59.69 & -- & -- & -- \\
\hline period & Treatments & 6 & 454.00 & 75.67 & $56.75^{*}$ & 4.46 \\
& Error & 14 & 18.67 & 1.33 & -- & -- \\
\hline
\end{tabular}

* indicates significant difference between treatment; ns indicates non-significant difference between treatment

\section{Cost-effectiveness of fire bricks}

Cost-effectiveness of the fire bricks manufactured from various organic waste was calculated based on local market prices. The price of fuel bricks prepared from various combinations of these materials is also less than that of the control (fuel wood). The number above bars indicates $(\%)$ the fuel bricks prepared from the waste material are less expensive than the control (fuel wood) used as fuel (Fig. 6).

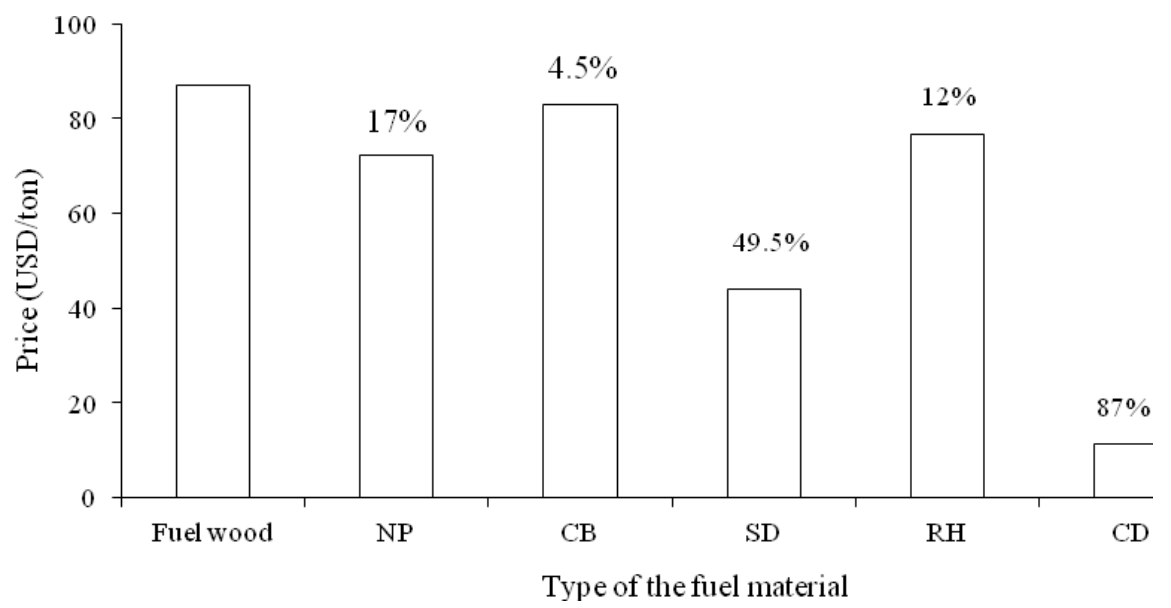

Figure 6. Cost-effectiveness of using organic waste for manufacturing fire bricks 
It was assessed that cow dung is $87 \%$ cheaper than the fuel wood followed by sawdust that is $49.5 \%$ less expensive than the fuel wood.

\section{Conclusion}

High quality and durable fire bricks can be made while using a combination of RHNP, RHCB, SDCB, CDCB, CDNP, SDCD in a ratio of 2:3 by volume. Moreover, the fire bricks produced from different organic wastes meet the recommended fuel characteristics as there was no significant difference in the flue gas temperature. The net burning efficiency range of fire bricks ranges from 39.7 to $58.9 \%$, significantly higher than that of the fuel wood. Contrary to fuel wood, fire brick emissions like $\mathrm{CO}, \mathrm{CO}_{2}$, $\mathrm{SO}_{2}$, NOx are within the permissible limits of NEQS. It is observed that fire bricks are eco-friendly and the use of these bricks will minimize the harmful effects of traditional fuel wood burning which would further minimize pressure on fuel budget of rural households. Fire bricks have the market potential due to their easy way of making, cost effectiveness and environment friendly nature. Similarly, this method recycles the waste into eco-friendly fuel bricks that are more efficient and reduce the burden on wood for energy. These bricks have high durability and can be transported anywhere without any damage to them.

Acknowledgements. Thanks are extended to Health Safety and Environment Consultants and Services, Lahore, Pakistan for providing technical facilities for flue gas analysis from fire bricks.

\section{REFERENCES}

[1] Chaney, J. (2010): Combustion characteristics of biomass briquettes. - PhD Thesis. The University of Nottingham. http://etheses.nottingham.ac.uk/1732/1/Combustion_Characteristics_of_Biomass_Briquet tes. pdf.

[2] Dong, C., Jin., B., Li, D. (2003): Predicting the heating value of MSW with a feed forward neural network. - Waste Management 23: 103-106.

[3] Emerhi, E. A. (2011): Physical and combustion properties of briquettes produced from sawdust of three hardwood species and different organic binders. - Advanced Applied Science Research 2(6): 236-246.

[4] Energy Commission (2008): Report on Wood Fuel Use in Ghana. An Outlook for the Future. - Energy Commission, Ghana.

[5] Enweremadu, C. C., Ojediran, J. O., Oladeji, J. T., Afolabi, I. O. (2004): Evaluation of energy potential of husks from soy-beans and cowpea. - Science Focus 8: 18-23.

[6] Evan, S. (2014): Is burning wood for energy worse for climate than coal? - Climate Brief, UK. Accessed on [30.04.2018]. https://www.carbonbrief.org/is-burning-wood-forenergy-worse-for-the-climate-than-coal.

[7] Fernandes, R. K., Marangoni, C., Souza, O., Sellin, N. (2013): Thermochemical characterization of banana leaves as a potential energy source. - Energy Conversion and Management 75: 603-608.

[8] Fetter, C. W. (2001): Applied Hydrogeology, 4th ed. - Prentice Hall, Upper Saddle River, New Jersey, USA.

[9] GOP (2016): Punjab Environmental Quality Standards for Industrial Gaseous Emissions. - The Punjab Gazette, Government of Punjab. 
[10] IEA (2007): Renewable in Global Energy Supply: An IEA Fact Sheet. - International Energy Agency, Paris.

[11] Ishrat, M. M., Lakshmi, K. (2014): Combustion analysis of fuel briquettes and fabrication of fuel briquetting machine. - International Journal of Emerging Technology and Advanced Engineering 4: 12.

[12] Kavitha, E. S., Joseph, K. (2007): Biomethanation of vegetable wastes. - J. Inst. Public Health Engineering 3: 11-19.

[13] Maia, B. G. D. O., Souza, O., Marangoni, C., Hotza, D., Oliveira, A. P. N. D. (2014): Production and characterization of fuel briquettes from banana leaves waste. - Chemical Engineering Transactions 37: 439-444. DOI: 10.3303/CET1437074.

[14] Mosler, H. J., Drescher, S., Zurbrugg, C., Rodriguez, T. C., Miranda, O. G. (2006): Formulating waste management strategies based on waste management practices of households in Santiago de Cuba, Cuba. - Habitat International 30(4): 849-862.

[15] Oladeji, J. T. (2010): Fuel characterization of briquettes produced from corncob and rice husk resides. - Pacific Journal of Science and Technology 11(1): 101-106.

[16] Raymer, A. K. P. (2006): A comparison of avoided greenhouse gas emissions when using different kind of wood energy. - Biomass and Bioenergy 30: 605-617.

[17] Styles, D., Thorne, F., Jones, M. B. (2008): Energy crops in Ireland: an economic comparison of willow and miscanthus production with conventional farming systems. Biomass Bioenergy 32: 407-421.

[18] Vongsaysana, S. (2009): Comparison of the physical chemical properties of briquette charcoal and wood charcoal. - Environment and Natural Resource Journal 7: 12-24.

[19] Wilaipon, P. (2007): physical characteristics of maize cob briquettes under moderate die pressure. - American Journal of Applied Science 4: 995-998. 